J.-P. BESSON
S. SCHILT
S. $^{1,}$
F. SAUSER
E. ROCHAT $^{2}$
P. HAMEL

F. SANDOZ
M. NIKLÈS
L.
LHÉVENAZ

\section{Multi-hydrogenated compounds monitoring in optical fibre manufacturing process by photoacoustic spectroscopy}

\author{
${ }^{1}$ Ecole Polytechnique Fédérale de Lausanne (EPFL), Nanophotonics and Metrology Laboratory, \\ 1015 Lausanne, Switzerland \\ 2 Omnisens SA, Riond-Bosson 3, 1110 Morges, Switzerland \\ ${ }^{3}$ Daetwyler Fiber Optics SA, Route de la Gare 70, 2017 Boudry, Switzerland
}

Received: 31 March 2006/Revised version: 26 May 2006 (C) Springer-Verlag 2006

\begin{abstract}
Sub-ppm hydrogen chloride $(\mathrm{HCl})$ and water vapour $\left(\mathrm{H}_{2} \mathrm{O}\right)$ monitoring using photoacoustic spectroscopy in optical fibre manufacturing is reported. The development and performance of a sensor based on an acoustic resonant configuration is described, and on-site measurements are presented. Two DFB lasers emitting in the $1370 \mathrm{~nm}$ and $1740 \mathrm{~nm}$ range were used for the detection of $\mathrm{H}_{2} \mathrm{O}$ and $\mathrm{HCl}$, respectively. A detection limit (defined for a $\mathrm{SNR}=3$ ) of $60 \mathrm{ppb}$ for $\mathrm{HCl}$ and $40 \mathrm{ppb}$ for $\mathrm{H}_{2} \mathrm{O}$ was achieved. Contamination sources of the carrier gas used for the fibre preform manufacturing are identified and discussed.
\end{abstract}

PACS 42.62.Fi; 43.35.Ud

\section{$1 \quad$ Introduction}

Trace gas analysis using laser diode photoacoustic spectroscopy (PAS) is a well established technique suitable for many applications such as environmental monitoring [1] or industrial process control $[2,3]$. This method enables multi-components analysis, real-time and continuous measurement and provides an excellent linearity over several orders of magnitude and a great selectivity by using singlemode light-emitting sources. In addition, the use of standard semiconductor telecommunication laser diodes in combination with a properly designed photoacoustic (PA) cell enables reaching of a sub-ppm detection limit for many species.

In this paper, we report a PA sensor developed to monitor hydrogen chloride $(\mathrm{HCl})$ and water vapour $\left(\mathrm{H}_{2} \mathrm{O}\right)$ at the sub-ppm level for process control in the manufacturing of the novel low-water-peak fibres used in optical telecommunications. These new type of fibres, also called metro fibres or zero-water-peak fibres (ZWPFs), are designed to enable optical transmission in the $E$-band $(1360-1460 \mathrm{~nm})$, so that this window can be opened for implementing cost-effective coarse wavelength division multiplexing (CWDM) technology for current or future network applications [4]. In addition, a lower attenuation in the $S$-band (1460-1530 nm) makes optical amplification by Raman effect possible instead of the classical

Fax: +41-21-693 2614, E-mail: jean-philippe.besson@epfl.ch use of fibre lasers, the pump being spectrally positioned in the $E$-band. The presence of a strong $\mathrm{OH}^{-}$absorption peak centered at $1390 \mathrm{~nm}$ in standard silica optical fibres is mainly due to moisture contamination that occurs during the manufacturing process of the fibre preform, usually realised by modified chemical vapour deposition (MCVD). In this process, various gaseous chlorides $\left(\mathrm{SiCl}_{4}, \mathrm{GeCl}_{4}, \mathrm{POCl}_{3}\right)$ are diluted in a carrier gas that flows through a rotating fused silica tube. The carrier gas mainly contains oxygen $\left(\mathrm{O}_{2}\right)$, together with helium (He) at a concentration of a few tens of percent in order to homogenise the gas temperature and therefore to increase the rate deposition of $\mathrm{GeO}_{2}$ and $\mathrm{SiO}_{2}$ on the inner wall of the silica tube. Silicon tetrachloride $\left(\mathrm{SiCl}_{4}\right)$ and germanium tetrachloride $\left(\mathrm{GeCl}_{4}\right)$ are used to create the step index between the core and the cladding of the fibre. Phosphoric chloride $\left(\mathrm{POCl}_{3}\right)$ is used in the cladding in order to lower the vitrification temperature to avoid mechanical deformation of the tube. Typical gaseous chemical reactions occurring between the chlorides and oxygen during the manufacturing of the preform are the following [5]:

$$
\begin{aligned}
& \mathrm{SiCl}_{4}+\mathrm{O}_{2} \rightarrow \mathrm{SiO}_{2} \downarrow+2 \mathrm{Cl}_{2} \\
& \mathrm{GeCl}_{4}+\mathrm{O}_{2} \rightarrow \mathrm{GeO}_{2} \downarrow+2 \mathrm{Cl}_{2} \\
& 4 \mathrm{POCl}_{3}+\mathrm{O}_{2} \rightarrow 2 \mathrm{P}_{2} \mathrm{O}_{5} \downarrow+6 \mathrm{Cl}_{2}
\end{aligned}
$$

When water contamination diffuses in the gas mixture, $\mathrm{HCl}$ is produced as a result of the strong reactivity between water and chloride compounds:

$$
\begin{aligned}
& \mathrm{SiCl}_{4}+2 \mathrm{H}_{2} \mathrm{O} \rightarrow \mathrm{SiO}_{2} \downarrow+4 \mathrm{HCl} \\
& \mathrm{GeCl}_{4}+2 \mathrm{H}_{2} \mathrm{O} \rightarrow \mathrm{GeO}_{2} \downarrow+4 \mathrm{HCl} \\
& \mathrm{POCl}_{3}+3 \mathrm{H}_{2} \mathrm{O} \rightarrow \mathrm{H}_{3} \mathrm{PO}_{4} \downarrow+3 \mathrm{HCl}
\end{aligned}
$$

The measurement of the $\mathrm{HCl}$ concentration in the process gas is therefore an excellent indicator of the quantity of water contamination present in the gas mixture.

The main source of contamination generally occurs during the replacement of an empty bubbler containing the chlorides. Unfortunately, this change has to be made manually for the $\mathrm{POCl}_{3}$ container and requires opening of the gas line, resulting in water ingress into the line. The purge time after the container's exchange is a critical parameter, since it directly influences the production of new preforms. The developed PA 


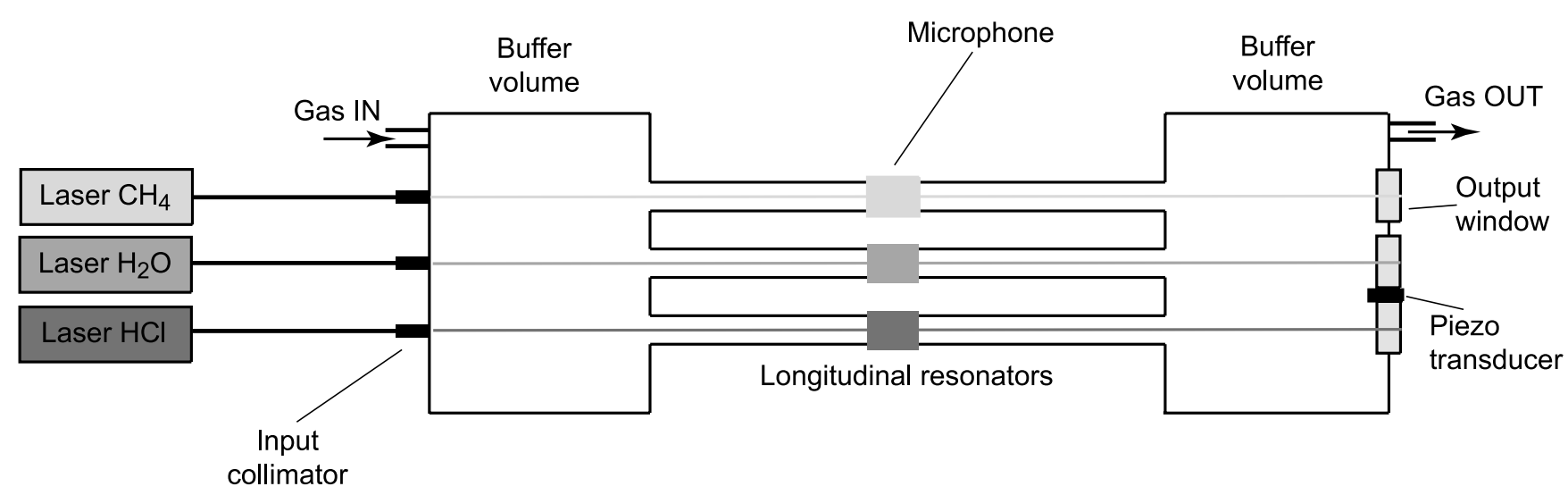

FIGURE 1 Schematic view of the PA cell consisting of three longitudinal modes operating in their first longitudinal mode. A piezo transducer is used for resonance frequency tracking

sensor is therefore used as a diagnostic instrument to monitor the quality of the carrier gas after the replacement of a bubbler.

\section{Experimental details and calibration \\ 2.1 Set-up}

The PA sensor is based on resonant PAS in combination with semiconductor laser diodes emitting in the nearinfrared region. The resonant PA cell consists of three parallel tubes, each operating as an acoustic resonator, terminated by two larger buffer volumes (see Fig. 1). This configuration offers the possibility of measuring up to three gases simultaneously using three different lasers (one laser beam per tube). For example, the sensor has been designed to monitor $\mathrm{CH}_{4}, \mathrm{H}_{2} \mathrm{O}$ and $\mathrm{HCl}$ using three DFB lasers emitting respectively in the $1650 \mathrm{~nm}, 1370 \mathrm{~nm}$ and $1740 \mathrm{~nm}$ range. For the on-site measurements reported here, methane has not been considered yet and the corresponding laser was simply not connected. The resonators oscillate in their first longitudinal mode at a frequency around $1 \mathrm{kHz}$ in air. A gold coating was deposited on the inner surface of the cell to reduce adsorptiondesorption processes. This is an important aspect to achieve accurate measurements of gas traces with a reasonable response time in the case of polar molecules such as $\mathrm{HCl}$ and $\mathrm{H}_{2} \mathrm{O}$, which tend to stick to the walls of the cell. Heating of the cell is an alternative technique to reduce these kind of processes [6], which is however difficult to implement in an industrial environment. Further developments of the sensor will include the possibility of heating the cell. Sensitive electret microphones, placed in the centre of each resonator, are used to detect the acoustic signals. The PA signal is amplified and measured using a lock-in amplifier with a time constant usually set to $10 \mathrm{~s}$. The pigtailed DFB lasers connected to fibered collimators are directly mounted on the outer flange of the cell and each of them was aligned along the axis of one resonator. An active tracking of the acoustic resonance frequency has been implemented with a piezo-electric transducer used as a speaker to secure long-term unattended operation of the instrument. Additional details on the sensor can be found in $[7,8]$.

In order to monitor $\mathrm{HCl}$ and $\mathrm{H}_{2} \mathrm{O}$ concentrations in the manufacturing process of the ZWPF, the PA sensor has been inserted in a line parallel to the process line (Fig. 2). The carrier gas was made of $\mathrm{He}, \mathrm{O}_{2}$ and an additional $\mathrm{O}_{2}$ flow saturated with either $\mathrm{SiCl}_{4}, \mathrm{GeCl}_{4}$ or $\mathrm{POCl}_{3}$. The chloridesaturated gas was generated by bubbling pure $\mathrm{O}_{2}$ in a container filled with $\mathrm{SiCl}_{4}, \mathrm{GeCl}_{4}$ or $\mathrm{POCl}_{3}$ at fixed temperatures of respectively $39^{\circ} \mathrm{C}, 39^{\circ} \mathrm{C}$ and $32^{\circ} \mathrm{C}$. Measurements were performed in a gas mixture which slightly differed from the carrier gas used in the process (see Tables 1 and 2). The principal reason is that we aimed at quantifying the contribution of each of the chlorides separately, whereas $\mathrm{SiCl}_{4}, \mathrm{GeCl}_{4}$ and $\mathrm{POCl}_{3}$ are mixed together in the process gas. A total flow rate of $1000 \mathrm{sccm}$ (standard cubic centimeter per minute) has been used in order to grant a fast response time without adding any extra acoustic noise. Electro-valves were used to commute from the preform line to the measurement line, making trace gas monitoring without preform processing possible. The precise gas mixture compositions were chosen in order to have a similar resonance frequency as used in the calibration phase (see Sect. 2.2). The final concentrations and gas mixtures used for $\mathrm{HCl}$ and $\mathrm{H}_{2} \mathrm{O}$ measurements are summarised in Table 1 .

Before starting trace gas measurements, the PA cell was continuously purged with nitrogen $\left(\mathrm{N}_{2}\right)$ over three days to assure that no impurities were introduced by the sensor. This is particularly important for $\mathrm{H}_{2} \mathrm{O}$ due to the sticky nature of

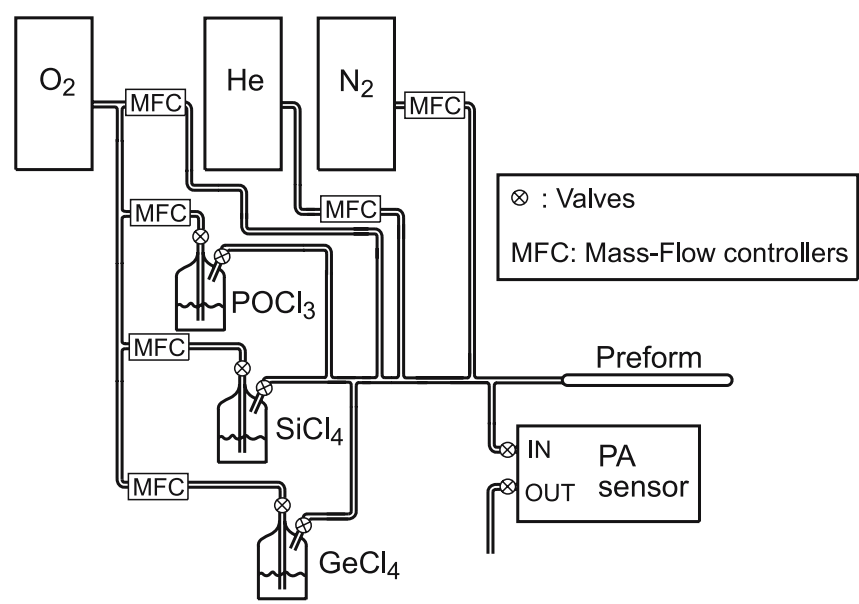

FIGURE 2 Gas distribution system for the preform manufacturing. The PA sensor is inserted in a line parallel to the process line. Mass-flow controllers (MFC) and electro-valves enable dilutions of different gas mixtures 


\begin{tabular}{lcccccr}
\hline Chloride & $T\left({ }^{\circ} \mathrm{C}\right)$ & $\begin{array}{c}\text { Saturated vapour } \\
\text { pressure }(\mathrm{mb})[13]\end{array}$ & $\mathrm{He}(\mathrm{sccm})$ & $\mathrm{O}_{2}(\mathrm{sccm})$ & $\begin{array}{c}\mathrm{O}_{2}+\text { chloride } \\
(\mathrm{sccm})\end{array}$ & $\begin{array}{c}\text { Chloride } \\
\text { concentration }(\%)\end{array}$ \\
\hline $\mathrm{POCl}_{3}$ & 32 & 66.5 & 450 & 150 & $400+29$ & 2.79 \\
$\mathrm{SiCl}_{4}$ & 39 & 534.6 & 700 & 200 & $100+115$ & 10.31 \\
$\mathrm{GeCl}_{4}$ & 39 & 215.9 & 500 & 400 & $100+28$ & 2.68 \\
\hline
\end{tabular}

TABLE 1 Gas mixtures and chloride concentrations used for $\mathrm{HCl}$ and $\mathrm{H}_{2} \mathrm{O}$ monitoring

\begin{tabular}{lcccccc}
\hline \multirow{2}{*}{ Chloride } & \multicolumn{2}{c}{$\begin{array}{c}\text { Chloride concentration (\%) } \\
\text { Meas. gas }\end{array}$} & $\begin{array}{c}\text { Process gas } \\
\text { Peas. gas }\end{array}$ & Mentration (ppm) & \multicolumn{2}{c}{$\mathrm{HCl}$ concentration (ppm) } \\
Process gas & Meas. gas & Process \\
\hline $\mathrm{POCl}_{3}$ & 2.79 & 0.088 & 0.92 & 0.03 & 15 & 0.47 \\
$\mathrm{SiCl}_{4}$ & 10.31 & 7.85 & - & - & 2.6 & 2 \\
$\mathrm{GeCl}_{4}$ & 2.68 & 2.81 & 0.095 & 0.1 & 0.76 & 0.8 \\
\hline
\end{tabular}

TABLE 2 Comparison of chlorides, $\mathrm{H}_{2} \mathrm{O}$ and $\mathrm{HCl}$ concentrations between the buffer gas used for PAS measurements and the process gas used in optical fibre manufacturing

this polar molecule [9] and its high natural abundance, since the PA cell has been subject to a $\mathrm{H}_{2} \mathrm{O}$ concentrations as high as $1 \%$, corresponding to typical humidity content of air. During the campaign, a continuous $\mathrm{N}_{2}$ flow of about $1000 \mathrm{sccm}$ passed through the cell when no chloride was flowing through the sensor in order to maintain a clean environment. $\mathrm{HCl}$ and $\mathrm{H}_{2} \mathrm{O}$ were measured during an 11 day period after the insertion of a new $\mathrm{POCl}_{3}$ bubbler in order to evaluate the required purge time of the installation. After this time a preform can be manufactured to fulfill the requirements for a low-water-peak fibre. At the end of the campaign, additional measurements were carried out with $\mathrm{SiCl}_{4}$ and $\mathrm{GeCl}_{4}$.

\subsection{Calibration of the PA sensor}

Calibration of the PA sensor was performed in the laboratory under similar conditions to those experienced onsite. Different gas mixtures and various concentrations of hydrogenated compounds were obtained from certified cylinders of $\mathrm{HCl}, \mathrm{H}_{2} \mathrm{O}, \mathrm{He}$ and $\mathrm{O}_{2}$ using mass-flow controllers. The total gas flow was maintained at $1000 \mathrm{sccm}$ at atmospheric pressure. The influence of the chloride compounds was not considered in the calibration phase, as these chemical products are very corrosive, difficult to handle and need neutralisation processing before being rejected into the air. However, since the concentration of $\mathrm{POCl}_{3}$ and $\mathrm{GeCl}_{4}$ did not exceed $3 \%$ and $\mathrm{SiCl}_{4} 10.5 \%$ in the measured carrier gas (see Table 1), their influence on the spectroscopic parameters (foreign-gas broadening coefficient of the considered absorption line) is expected to be minor. The effect of the chlorides on the resonance frequency was taken into account, since the gas mixture in the manufacturing was adapted to obtain the same resonance frequency as used for the calibration.

A typical calibration curve for $\mathrm{HCl}$ was obtained by diluting a certified mixture of $50 \mathrm{ppm} \mathrm{HCl}$ buffered in $\mathrm{He}$, with pure $\mathrm{O}_{2}$ and $\mathrm{He}\left(60 \% \mathrm{O}_{2}\right.$ and $\left.40 \% \mathrm{He}\right)$ (Fig. 3a). The resonance frequency and the quality factor obtained in these conditions were respectively $1137 \mathrm{~Hz}$ and 20. Calibration for water vapour at a low mixing ratio is delicate owing to the polarity of the molecule and its resulting adsorption-desorption processes problems [6]. Therefore, higher $\mathrm{H}_{2} \mathrm{O}$ concentrations (up to a few ppm) in combination with a flow of $1000 \mathrm{sccm}$ have been used to determine the calibration slope and to ex- trapolate the detection limit (Fig. 3b). The range of $\mathrm{H}_{2} \mathrm{O}$ concentrations considered in the calibration $(5-10 \mathrm{ppm})$ is of the same order of magnitude as that encountered on-site after the change of the $\mathrm{POCl}_{3}$ bubbler $(0.4-1.8 \mathrm{ppm})$. Water vapour
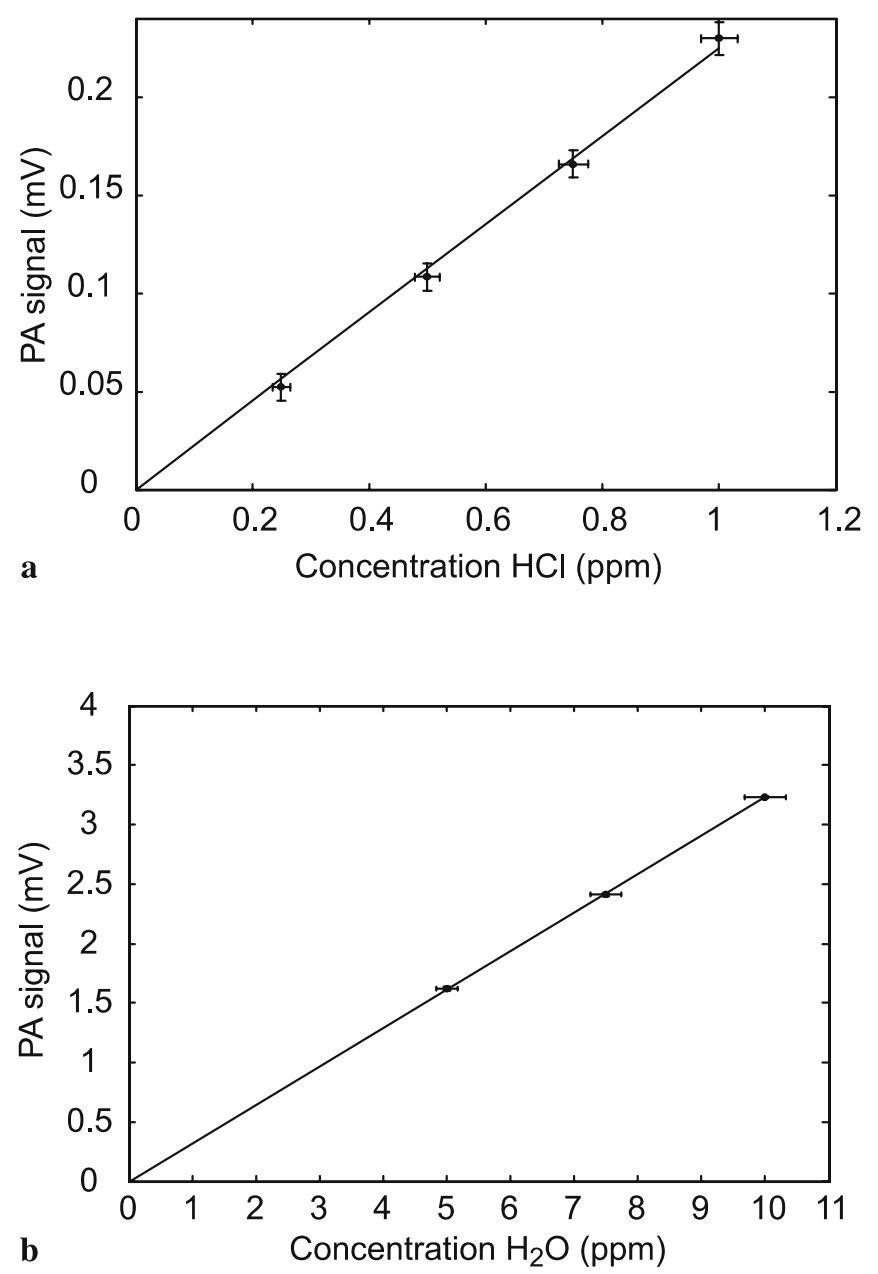

FIGURE 3 Calibration curves for (a) $\mathrm{HCl}$ and (b) $\mathrm{H}_{2} \mathrm{O}$ in a $60 \% \mathrm{O}_{2}-40 \%$ He mixture. Error bars shown on the plot correspond to the uncertainty on $\mathrm{HCl}$ and $\mathrm{H}_{2} \mathrm{O}$ concentrations generated with the MFCs (horizontal axis) and to the standard deviation of the PA signal recorded in a 5-min period (vertical axis) The integration time was $1 \mathrm{~s}$ for $\mathrm{HCl}$ and $10 \mathrm{~s}$ for $\mathrm{H}_{2} \mathrm{O}$. Dots are the measured datapoints and the line is the result of a linear fit 
monitored in $\mathrm{GeCl}_{4}$ resulted in a lower level in the $100 \mathrm{ppb}$ range, but previous results obtained for methane monitoring using the same set-up have shown an excellent linearity over several orders of magnitude (5000-0.5 ppm) and down to a value of a few detection limits [10]. $\mathrm{H}_{2} \mathrm{O}$ calibration was performed by diluting a certified mixture of $50 \mathrm{ppm} \mathrm{H}_{2} \mathrm{O}$ buffered in nitrogen with $\mathrm{O}_{2}$ and $\mathrm{He}$, so that a residual of several percent of $\mathrm{N}_{2}$ was still present in the $\mathrm{He}-\mathrm{O}_{2}$ mixture. A detection limit (defined for a signal-to-noise ratio $\mathrm{SNR}=3$ and with $10 \mathrm{~s}$ integration time) of $60 \mathrm{ppb}$ for $\mathrm{HCl}$ and $40 \mathrm{ppb}$ for $\mathrm{H}_{2} \mathrm{O}$ resulted from these calibration curves.

Finally, the modulation parameters of the lasers were optimised to maximize the PA signal [10] and were kept constant during the whole calibration procedure. The same parameters were then used for the on-site measurements.

\section{Results and discussion}

Figure 4 shows representative measurements of $\mathrm{HCl}$ and $\mathrm{H}_{2} \mathrm{O}$ performed in the gas mixtures described in Table 1 immediately after the change of the $\mathrm{POCl}_{3}$ bubbler and one day after. A very high concentration of $\mathrm{HCl}$ (up to $0.3 \%$ ) was present at the beginning, showing that the carrier gas was highly contaminated due to the change of the $\mathrm{POCl}_{3}$ container. In contrast, the water vapour level was in the ppm range due to the fact that most of the water content present in the gas was readily transformed into $\mathrm{HCl}$ (see chemical reaction (4)-(6)). As oxygen was flowing through the $\mathrm{POCl}_{3}$ bubbler, the $\mathrm{HCl}$ concentration decreased along with time due to the purge of the container. The evolution of $\mathrm{HCl}$ and $\mathrm{H}_{2} \mathrm{O}$ concentrations over 11 days is presented in Figs. 5 and 6. The variation of the $\mathrm{HCl}$ concentration shows a regular decrease during the purge of the container: on day one, the bubbler was changed, producing a high degree of water contamination transformed into $\mathrm{HCl}$ and after a continuous purge of the container with $\mathrm{O}_{2}$ over $49 \mathrm{~h}$, the concentration decreased to reach a level of $5 \mathrm{ppm}$. No purging and no measurements were performed the following day (day four) as a result of a machine maintenance. Therefore, a higher $\mathrm{HCl}$ concentration of $40 \mathrm{ppm}$ was observed at the beginning of day five due to water desorption in the teflon head of the container when the $\mathrm{O}_{2}$ purge was interrupted. The concentration decreased down to $21 \mathrm{ppm}$ after $2 \mathrm{~h}$ of purging. After a new break of two days (week-end), the concentration increased again up to $77 \mathrm{ppm}$ to reach a level of $15 \mathrm{ppm}$ after $5 \mathrm{~h}$ of continuous flow of $\mathrm{O}_{2}$. The evolution of the water vapour concentration over these days was quite different as the range of observed variations (from a maximum of $1.8 \mathrm{ppm}$ to a minimum of $0.40 \mathrm{ppm}$ ) was much reduced compared to $\mathrm{HCl}$, and the $\mathrm{H}_{2} \mathrm{O}$ concentration did not change in a regular way. During the purge, the measured $\mathrm{H}_{2} \mathrm{O}$ concentration decreased with time at high $\mathrm{HCl}$ levels (day 1 and the beginning of day 2), but tended to increase in an intermediate range of $\mathrm{HCl}$ concentration of $10-100 \mathrm{ppm}$ (see day 2,5 or 8). To explain this behaviour, we believe that the measured $\mathrm{H}_{2} \mathrm{O}$ signal originates from two different contributions. The first one is due to the real water vapour content in the gas that results from residual water introduced in the line during the exchange of the $\mathrm{POCl}_{3}$ bubbler and not transformed into $\mathrm{HCl}$. This contribution is expected to be dominant in the early phase of the purge and to decrease with the purge time
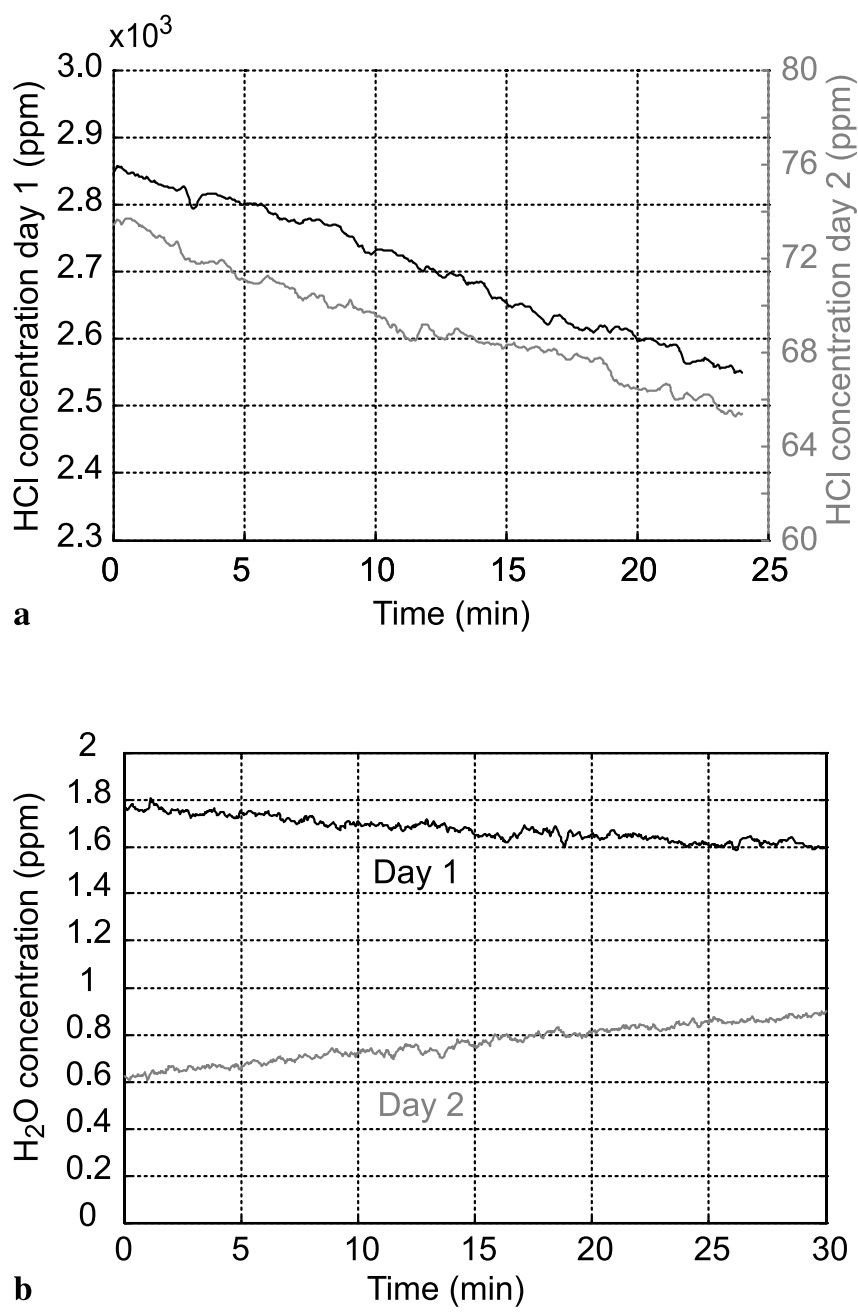

FIGURE 4 Typical concentration measurements over several minutes. (a) $\mathrm{HCl}$ and (b) $\mathrm{H}_{2} \mathrm{O}$ concentration on day one (black curve) and day two (grey curve) after the $\mathrm{POCl}_{3}$ bubbler exchange. The decrease of the concentration of $\mathrm{HCl}$ is due to purging of the $\mathrm{POCl}_{3}$ container by a continuous flow of $\mathrm{O}_{2} . \mathrm{H}_{2} \mathrm{O}$ concentration variations originate from two contributions: real water vapour content in the process gas and desorption effects (see text for details)

in a similar way as observed for the $\mathrm{HCl}$ concentration (see Fig. 4). A second contribution may result from a process of water desorption from the walls of the cell and possibly from the line. This contribution seems to be significant after a certain purge duration, corresponding to an intermediate range of $\mathrm{HCl}$ concentrations of $10-100 \mathrm{ppm}$. This process is believed to be responsible for an increase of the observed $\mathrm{H}_{2} \mathrm{O}$ concentration as illustrated in Fig. 4b.

It must be emphasized that the concentration of these contaminants is much lower in the real carrier gas used in the preform manufacturing process, since the total carrier gas mixture is different. The $\mathrm{POCl}_{3}$ concentration in the process is $0.088 \%$ (compared to $2.79 \%$ for the measurements) meaning that $\mathrm{HCl}$ and $\mathrm{H}_{2} \mathrm{O}$ concentrations are reduced accordingly (see Table 2). However, the sensitivity of the sensor is sufficient to monitor $\mathrm{HCl}$ in the real process gas.

After these eight days of purging, a first preform was manufactured and a fibre was drawn in order to analyse its different parameters, in particular the spectral attenuation. To 


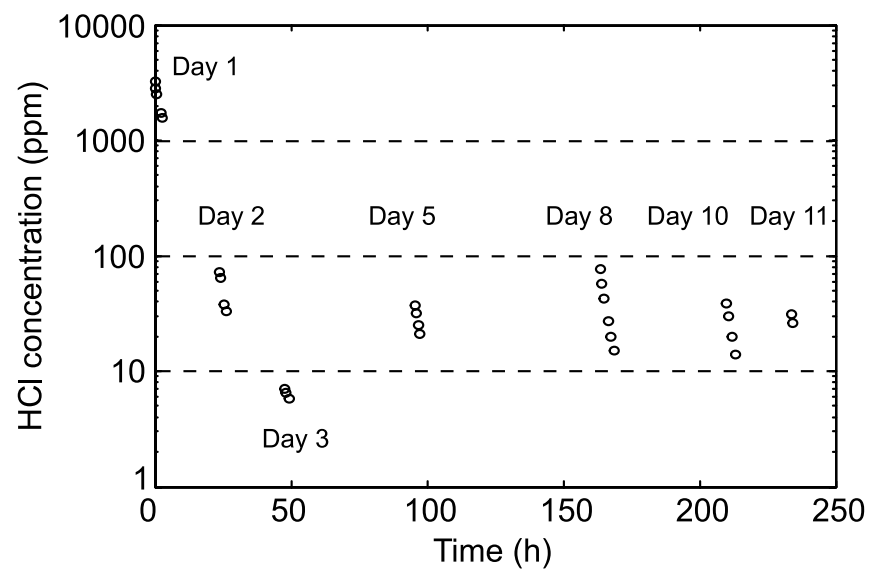

FIGURE $5 \mathrm{HCl}$ concentration level evolution over 11 days. The grouped circles represent several measurements performed on the same day during a time period varying from a few tens of minutes up to one hour. Each circle corresponds to one measurement point (integration time of $10 \mathrm{~s}$ ) taken at the beginning or at the end of that period

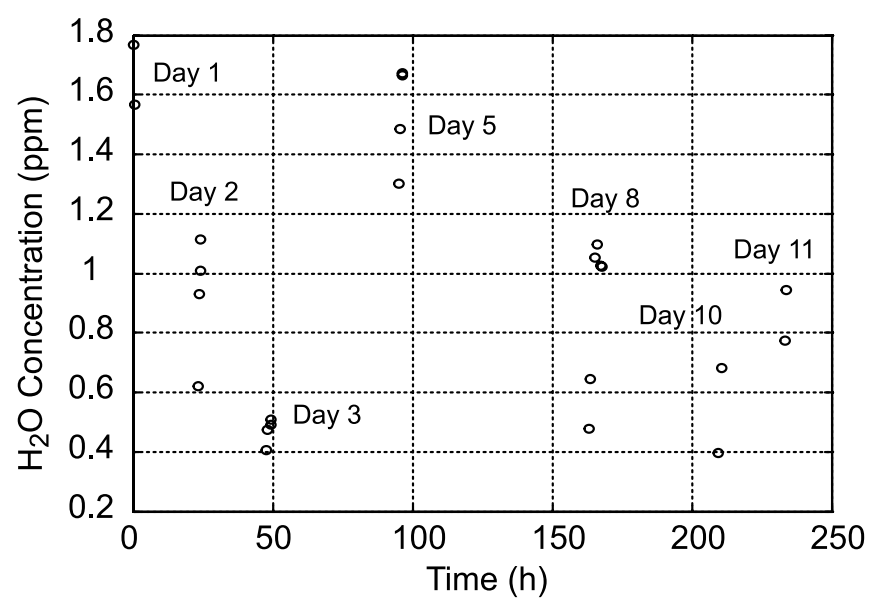

FIGURE $6 \quad \mathrm{H}_{2} \mathrm{O}$ concentration level evolution over 11 days. The grouped circles represent several measurements performed on the same day during a time period varying from a few tens of minutes up to one hour. Each circle corresponds to one measurement point (integration time of $10 \mathrm{~s}$ ) taken at the beginning or at the end of that period

be compliant with ITU recommendation for a low-water-peak fibre [11], the attenuation measured at the maximum of the $\mathrm{OH}^{-}$peak at $1383 \mathrm{~nm}$ must be lower than the attenuation at $1310 \mathrm{~nm}$ after hydrogen $\left(\mathrm{H}_{2}\right)$ ageing [12]. Attenuation curves of the fibre manufactured from the preform processed on day nine is presented in Fig. 7. A second fibre manufactured seven days later is shown in the same figure. These measurements were carried out after the drawing of the fibre, but without performing $\mathrm{H}_{2}$ ageing. However, $\mathrm{H}_{2}$ ageing is not systematically performed and a security margin of $0.02 \mathrm{~dB} / \mathrm{km}$ is added to the attenuation coefficient to take this effect into account. A maximum of $0.34 \mathrm{~dB} / \mathrm{km}$ at $1383 \mathrm{~nm}$ is acceptable for the fibre to be considered as a low-water-peak fibre. On Fig. 7, no significant attenuation improvement in the $E$-band and $S$ band region can be noticed between the two fibres. In addition, both fibres present an attenuation of $0.320 \mathrm{~dB} / \mathrm{km}$ (fibre of day eight) and $0.318 \mathrm{~dB} / \mathrm{km}$ (fibre of day 15) at $1383 \mathrm{~nm}$, which satisfies the criteria defined above.

Finally, $\mathrm{HCl}$ and $\mathrm{H}_{2} \mathrm{O}$ were monitored in gas mixtures containing $\mathrm{GeCl}_{4}$ and $\mathrm{SiCl}_{4}$ to identify the contribution of these

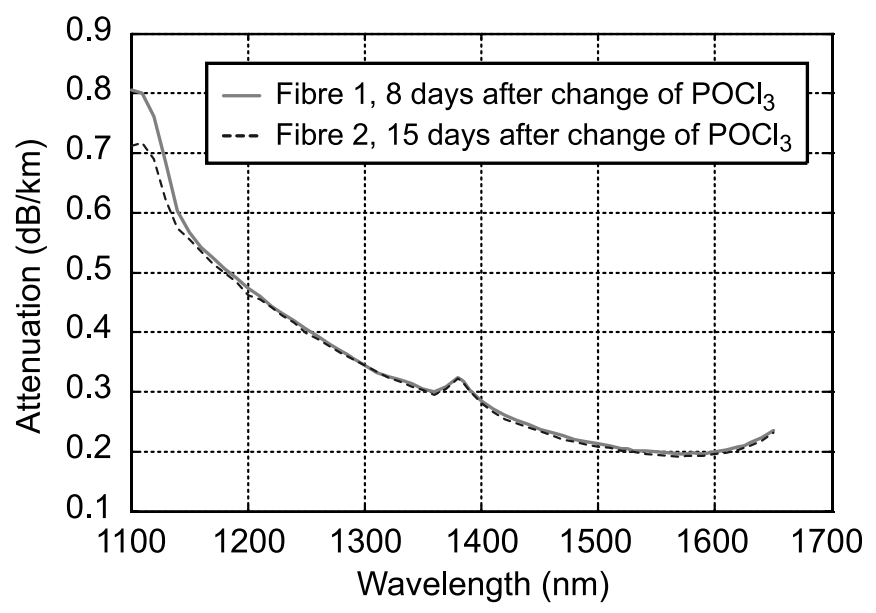

FIGURE 7 Attenuation of the low-water-peak fibres manufactured 8 days (solid line) and 15 days (dashed line) after the replacement of the $\mathrm{POCl}_{3}$ container
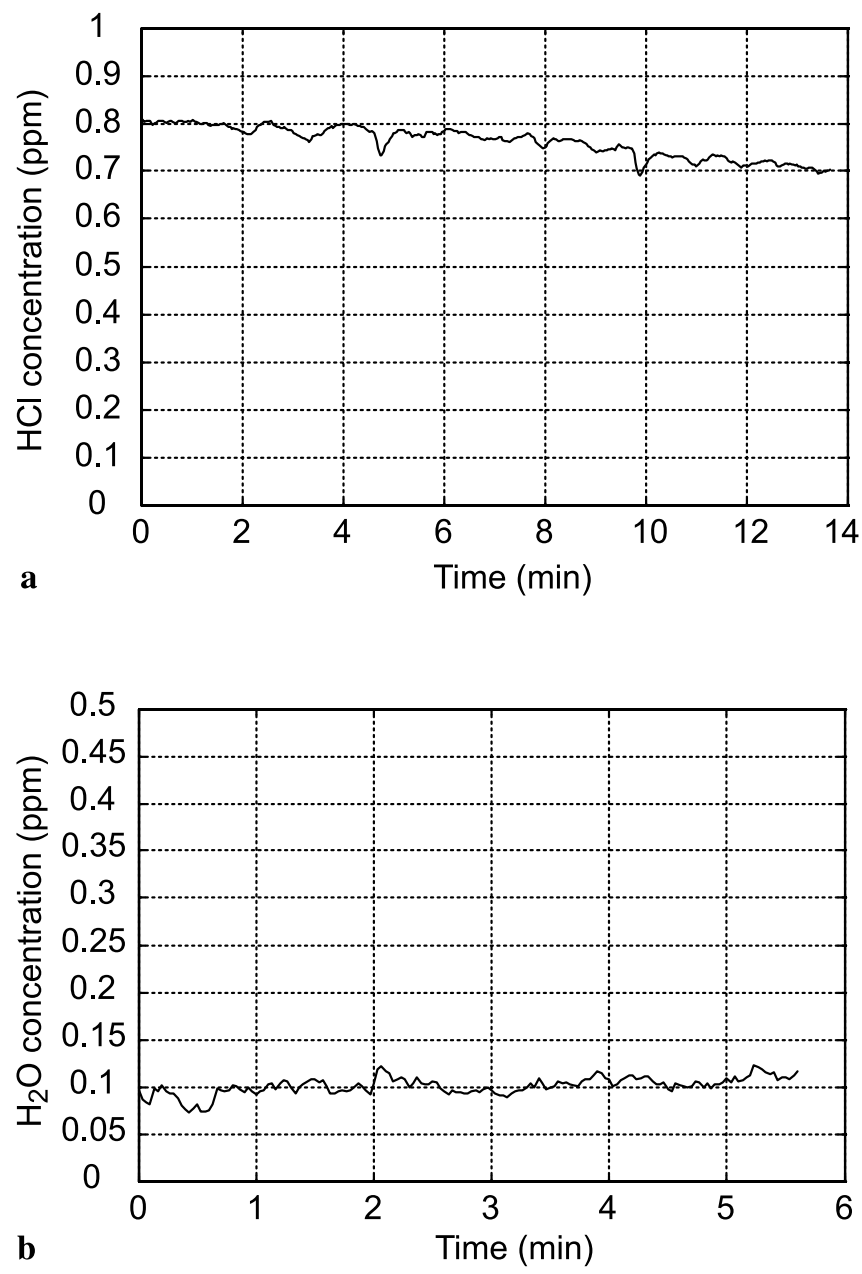

FIGURE $8 \mathrm{HCl}$ (a) and $\mathrm{H}_{2} \mathrm{O}$ (b) measurements in a gas mixture of $100 \mathrm{sccm} \mathrm{O} \mathrm{O}_{2}$ saturated with $\mathrm{GeCl}_{4}, 400 \mathrm{sccm} \mathrm{O} \mathrm{O}_{2}$ and $500 \mathrm{sccm} \mathrm{He}$

chloride compounds to the $\mathrm{OH}^{-}$peak. Figure 8 displays the measured concentrations in the case of $\mathrm{GeCl}_{4}$ for the gas mixtures described in Table 1. The measured concentrations were below $1 \mathrm{ppm}$ for $\mathrm{HCl}$ and around $0.1 \mathrm{ppm}$ for $\mathrm{H}_{2} \mathrm{O}$. The same measurements using $\mathrm{SiCl}_{4}$ are presented in Fig. 9. Unfortunately, $\mathrm{H}_{2} \mathrm{O}$ levels could not be measured due to technical 


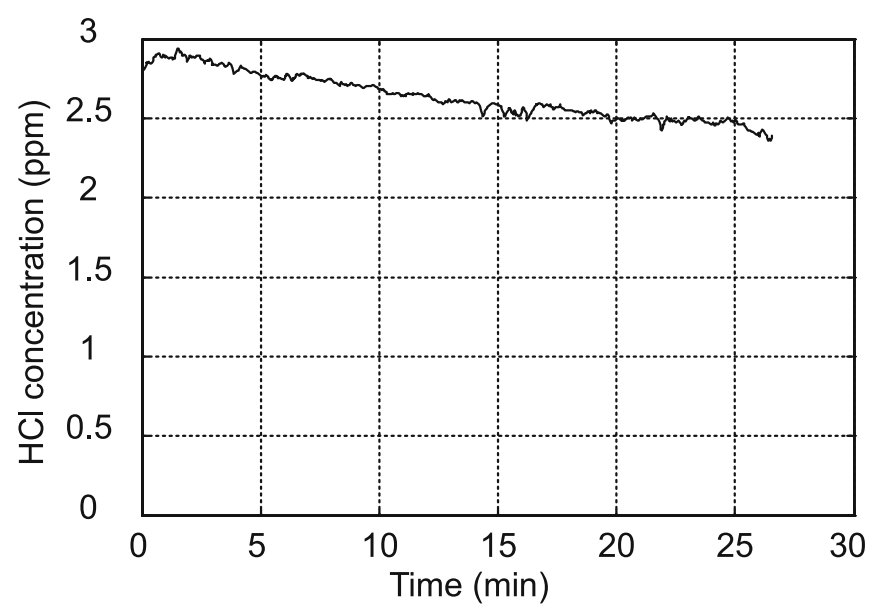

FIGURE $9 \mathrm{HCl}$ measurements in a gas mixture of $100 \mathrm{sccm} \mathrm{O}_{2}$ saturated with $\mathrm{SiCl}_{4}, 200 \mathrm{sccm} \mathrm{O} 2$ and $700 \mathrm{sccm} \mathrm{He}$

reasons. Here again, the gas mixtures used for the evaluation of $\mathrm{H}_{2} \mathrm{O}$ and $\mathrm{HCl}$ contamination were different from the one used in the process. The $\mathrm{GeCl}_{4}$ and $\mathrm{SiCl}_{4}$ concentrations used in the process are $2.81 \%$ and $7.85 \%$ respectively compared to $2.68 \%$ and $10.31 \%$ in our measurements, meaning that the measured $\mathrm{HCl}$ and $\mathrm{H}_{2} \mathrm{O}$ concentrations were comparable to the real process concentrations.

In order to compare the different contamination sources, typical chloride concentrations present in the process gas are used to extrapolate $\mathrm{HCl}$ and $\mathrm{H}_{2} \mathrm{O}$ concentrations from the obtained measurements (see Table 2). The substitution of the $\mathrm{POCl}_{3}$ bubbler results in an $\mathrm{HCl}$ concentration of $15 \mathrm{ppm}$ and $\mathrm{a} \mathrm{H}_{2} \mathrm{O}$ concentration of $0.92 \mathrm{ppm}$ (last measured points before preform manufacturing after eight days of purging) corresponding to $0.47 \mathrm{ppm}$ of $\mathrm{HCl}$ and $0.03 \mathrm{ppm}$ of $\mathrm{H}_{2} \mathrm{O}$ in the gas mixture used in the process. $\mathrm{HCl}$ and $\mathrm{H}_{2} \mathrm{O}$ concentrations resulting from the $\mathrm{GeCl}_{4}$ bubbler correspond to $0.76 \mathrm{ppm}$ and $0.10 \mathrm{ppm}$ in the process gas, respectively. Finally, $\mathrm{HCl}$ coming from the $\mathrm{SiCl}_{4}$ container results in a concentration of 2 ppm. This comparison shows that the principal contamination source comes from the $\mathrm{SiCl}_{4}$ container, considering that the purge of the $\mathrm{POCl}_{3}$ bubbler was done during a sufficient period of time.

\section{Conclusion}

Laser diode photoacoustic spectroscopy has been demonstrated to be an efficient and reliable measurement technique for trace gas analysis in process gases, and is especially well adapted to on-line continuous detection and quantification of contamination down to a few tens of $\mathrm{ppb}$. Sensitivity obtained using $\mathrm{mW}$-power laser diodes is sufficient to detect hydrogenated contaminants to a level low enough to secure a ZWPF production. Further improvements of the system are under way, and are aiming at an enhanced signal-to-noise ratio performing at ppb level sensitivity which will still broaden the range of application of the measurement technique.

ACKNOWLEDGEMENTS The authors would like to acknowledge the Commission of Technology and Innovation (CTI) of the Swiss Government for the financial support. The authors are also grateful to NTT Electronics Corporation for providing DFB lasers.

\section{REFERENCES}

1 R.A. Rooth, A.J.L. Verhage, W. Wouters, Appl. Opt. 29, 3643 (1990)

2 M.W. Sigrist, Rev. Sci. Instrum. 74, 486 (2003)

3 S. Schilt, L. Thévenaz, M. Niklès, L. Emmenegger, C. Hüglin, Spectrochim. Acta A 60, 3259 (2004)

4 K. Kincade, Laser Focus World 39, 97 (2003)

5 J. Gowar, Optical Communication Systems, Prentice-Hall Int. Series in Optoelec. (London, 1984)

6 A. Schmohl, A. Miklos, P. Hess, Appl. Opt. 40, 2571 (2001)

7 J.-P. Besson, S. Schilt, L. Thévenaz, Spectrochim. Acta A 60, 3449 (2004)

8 J.-P. Besson, S. Schilt, L. Thévenaz, Spectrochim. Acta A 63, 899 (2006)

9 Z. Bozoki, M. Szakall, A. Mohacsi, G. Szabo, Z. Bor, Sens. Actuators B 91, 219 (2003)

10 S. Schilt, J.-P. Besson, L. Thévenaz, In Second European Workshop on Optical Fiber Sensors, Vol. 5502, ed. by J.M. López-Higuera, B. Culshaw, SPIE, Bellingham, WA (2004), p. 317

11 International Telecommunication Union, ITU-T G652 (2003/03)

12 International Electrotechnical Commission (IEC), 60793-2-50 (200401)

13 Nat. Inst. of Standards and Technology, http://webbook.nist.gov/chemistry 